\title{
Games in the environmental context and their strategic use for environmental education
}

\author{
Branco, MAA. ${ }^{a *}$, Weyermüller, AR. ${ }^{a}$, Müller, EF. ${ }^{a}$, Schneider, GT. ${ }^{a}$, Hupffer, HM. ${ }^{a}$, Delgado, J. ${ }^{b}$ \\ Mossman, JB. ${ }^{a}, \mathrm{Bez}, \mathrm{MR} \cdot{ }^{a}$ and Mendes, TG. ${ }^{a}$ \\ ${ }^{a}$ Curso de Tecnologia em Jogos Digitais, Programa de Pós-Graduação em Indústria Criativa, \\ Laboratório de Objetos de Aprendizagem, Universidade Feevale, ERS-239 Road, 2755, Novo Hamburgo, RS, Brazil

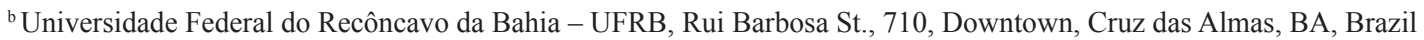 \\ *e-mail:marsal@feevale.br
}

Received: May 24, 2013 - Accepted: August 13, 2013 - Distributed: May 31, 2015

(With 3 figures)

\begin{abstract}
This article aims to present the productivity of the assumptions of Philosophical Hermeneutics (Gadamer, 1996) and his discovery of the logical, ontological and structural model of the game that takes place during the experience that is the basis of comprehension. Thus, digital games are proposed as manners, methods and ways to improve the understanding, interpretation and application of the concepts of Sustainability and Environmental Principles. The attraction of the game as a pedagogic space lays in the fact that it takes over and allows the player to internalize ecological sensitivity, something that happens during the play. Finally, the results show an augment on students' motivation, when using the game versus the traditional process.
\end{abstract}

Keywords: sustainability, games, digital learning constructs, education, game development.

\section{Games no contexto ambiental e seu uso estratégico para educação ambiental}

\section{Resumo}

Este artigo tem como objetivo apresentar a produtividade dos pressupostos da hermenêutica filosófica de Gadamer (1996) e sua descoberta do modelo lógico, ontológico e estrutural do jogo, que ocorre durante a experiência, que é a base da compreensão. Assim, os jogos digitais são propostos como maneiras, métodos e formas de melhorar a compreensão, interpretação e aplicação dos conceitos de princípios de sustentabilidade e meio-ambiente. A atração do jogo como espaço pedagógico reside no fato de que ele assume e permite que o jogador para internalizar sensibilidade ecológica, algo que acontece durante o jogo. Finalmente, os resultados obtidos demostram um incremento na motivação dos alunos, quando se utiliza o jogo ao invés dos métodos tradicionais.

Palavras-chave: sustentabilidade, jogos, constructos digitais de aprendizagem, educação, desenvolvimento de jogos.

\section{Introduction}

The creation of a juridical operator in relation to the socio-environmental law is in risk society a challenge for all law schools in Brazil. There are huge challenges in the legal field, hence the involvement of the academic community is required, as well, as a creative role in all areas of knowledge considering the complexity and effectiveness of national and international laws; human rights laws and all advances in legal relationships that impact the anthropocentric human relation with nature and requires the law operator insights about risks/hazards and about intergenerational equity.

Never before legal courses have been called to react, breaking traditional paradigms and bringing upon themselves the responsibility of building environmental laws in order to face serious ecological problems, and to break the vicious circle of identifying environmental law with legal system, reducing the jurist to a mere law expert. We must rethink shaping an environmental awareness in the law operator through a new philosophical paradigm. To achieve this goal, Law Schools cannot use only the model "classroom-teacher-student" and the exegesis of legal texts. It is essential, especially in environmental education, creating ludic learning spaces inter-, multi- and trans-disciplinary in order to reevaluate necessary assumptions to ensure a more effective protection to the environment from the perspective of intergenerational solidarity.

We have to seek new paradigms for understanding the complexity of environmental law and its interrelationship with other knowledge. Since the perspective of risk and scientific uncertainty are present in environmental decisions, it is vital to take a look at the present and future generations for the entire planet. 
An alternative to consider is the choice of philosophical hermeneutics which has a very important condition for understanding environmental law: the breaking of boundaries.

For this study, we propose the digital game as pedagogical strategic grounded in philosophical hermeneutics of Hans-Georg (Gadamer, 1996), as privileged matrix, able to illuminate a critical and reflective attitude under environmental law. The theoretical perspective is based on the phenomenological hermeneutics of Martin Heidegger (1999) (the question of "being" and "understanding") and, especially, philosophical hermeneutics of Hans-Georg Gadamer (the "game" as an authentic hermeneutics experience). Recognizing the scope of this study, it is believed that Gadamer can illuminate the construction of experiential games. His theoretical contributions are related to the process of using digital games in the teaching of environmental law, where it is always necessary to apply an understanding of the subject. The teaching of environmental law, to take on a hermeneutic, is able to contribute to the development of complex competencies that global risk society is demanding. Emphasis will be to (re) think the discipline of environmental law from the view that the interpretation is not an autonomous issue, apart from the understanding and application.

\subsection{The game as hermeneutics experience}

For Gadamer (1999), the game is a hermeneutic experience, as it requires the player to place himself before the world, both in understanding the rules and forces that are acting on a particular crop, as well as how the player finds itself within that cropping and finally, how he will act in response to these experiences.

The player, when unveiling/creating rules that give internal coherence to the game and when reacting to them in his decisions to play, is putting forward to an event. While playing the game, the player formulates theories, plans and acts in a single act. Playing becomes an experience of consciousness and focused reflection that to Heidegger (1999) is a powerful tool to guide the processes of knowledge. Playing becomes an event, and the event is the basis of all understanding. The player acts on the basis of perceptions, intuitions, thoughts, feelings, mixing logical and emotional decisions, synthesized in actions that act on the system. In practice, the game requires the player positioning, and when it acts in response, closes the hermeneutic cycle. An individual who are able to play chess, not necessarily understands the goal of the game, which is to immobilize the king, or even how to move each piece. We must also discover the hidden strategies of the opponent, his moves, his history, his habits, mannerisms, etc. Finally, we must act in response to all these signals. Anyway, playing chess is "to participate" in the study, responding and positioning in relation to it. You must have the context and its interpretation to play it.

The game is an event that guides the search for answers to the extent that it walks. The working method of the game does not respond to questions with Cartesian logic, but maps and dynamically responds to the acts of the game and develops deeper and deeper questions in order to guide us by an unexplored ground.

If we consider the issues of Environmental Law, we see that the mapping rules, the interpretation of movements and varied interests, and the need for action places put the law student in a situation of uncertainty in acting in an unexplored ground. The theory of risk society, translated by Ulrich Beck (2008) as reflexive modernity, created uncertainty, domain of not knowing, risks and organized irresponsibility among others, is a picture of this scenario. To Heidegger (1999), the game enables retrace the steps and walk the grounds of the precaution principle in a different way. The Precautionary Principle is precisely to show that there is no scientific certainty, no universal validity or mathematical rigor to anticipate threats and crises that can cause serious irreversible damage and incalculable risks to the environment.

An essential contribution is given by Gadamer (1999) when he considers the game in an ontological perspective. Gadamer begins his philosophical project based on the experience that occurs when facing a work of art and the playing of the game as a possibility to transform the being who is enjoying or playing it. What we experience is the expression of the work of art, because when one allows him or herself to experience it, appreciating a work of art, one receives something that is everlasting: the excitement of a moving film, the aesthetic shock facing something exceptionally beautiful (or ugly), a sense of victory by solving a puzzle in a game, the restlessness caused by certain works, etc. In the game concept developed by Gadamer, the participant experiences the game as a reality that transcends it and makes it share the same condition, which is the relation of relevance and distance.

Each player has its individual horizon, and the whole understanding in the game strategy represents a fusion of horizons. That is where the player brings to the game what he or she understood. So, Rohden reconstructs the game structure of Gadamer, stating that:

On the one hand it is logical, because it has fixed rules, universally valid, without which it would not occur. The rules of each game, with its own requirements, are explicable and universally recognized. On the other hand, the game is ontological because the subject is involved as a whole, not just from the point of view of knowledge - as a spectator that examines an object distantly - but also because while playing the game, the player experiences something and reveals their being (Rohden, 2002 p. 112).

Therefore, considering the theoretical contributions of Gadamer (1999), the pursued logic in allowing the player to perform an experience in the game and, thus, reveal its own being, is a different logic than the one that only articulates purely conceptual and rational determinations, i.e., a teaching that is based on pure concepts and on the norm placed in the functional and logic structure of a dogmatic 
cartesianism of the legal and environmental phenomenon and of the anthropocentric view of the environment.

In light of the above, we question: How to apply the logical-ontological structural model developed by Gadamer (1999) to teach Environmental Law? In situations of teaching and learning, the structural model of game developed by Gadamer opens a way to organize the class around learning communities that are confronted with certain environmental issues, and have as privileged actors to experience the three moments of an authentic hermeneutics experience: interpretation, comprehension and application.

As a practical response to Gadamer's theoretical construct about the game and its applicability as a hermeneutic experience, we seek to find out how the use of digital games for learning environmental issues can be used to enhance the understanding of complex phenomena and that, as a general rule, have a high degree of uncertainty. Next, we present a brief description of the potentials and the state of the art gaming industry and its uses in society.

\subsection{Digital games and the environmental education}

The game industry withholds in its processes the domain of some of the most sophisticated technologies in education/simulation/communications among tech industries. In countries like the United States, the gaming industry is responsible for many significant advances in educational processes, in public education, private education, and also by the companies and NGOs. Areas such as biology, ecology, economy, human resources, communication and others have systematically bet on games as a pedagogical tool or to create innovative learning processes (Prensky, 2001). These processes encompass all types of content: weather conditions, future scenarios, ecosystems, urban planning, accident prevention, crisis scenarios, crowd control, metropolitan transit, etc.

We did not choose the examples at random. They were selected in order to clarify that when we speak of digital games in the scope of this paper, it should be taken into account that they extrapolate the superficial expressions, which are entertainment games. In fact, the areas that focus on resources of research and development today find in games an essential methodological/procedural tool to the performance of their activities: neuroscience, engineering, biology, nanotechnology, energy, to mention only the most evident.

Ulrich (1997) proposes three ways in which games affect these industries.

\section{a) Optimizing processes}

Through simulation systems that allow direct manipulation and real-time feedback of complex and/ or high cost systems. Simulation games for transit or environment that emulate the operation of machines, such as airplanes, control stations or climate control are a few examples.

b) Increasing educational performance;

Through its ability of retaining attention of the player/ user, using seduction and engagement tools, proposed by the theories of digital games.

c) Stimulating innovation;

By applying methodologies from the game theory, the inherent problems in traditional industries are tensioned by ideas that do not respect the same kind of hierarchy and values traditionally constituted by the original areas, revealing new ways of thinking about problems. The teams that create and work are composed by effective interdisciplinary teams, which confront different ideas about the issues.

An interesting example of the first type is the training simulation systems of super cranes such as those ones used by Petrobrás (Oníria, 2010), developed today by national game developers (Figure 1).

The system allows emulating the environment and working conditions of an equipment/process which is difficult, expensive and often dangerous to master (Mendes, 2012). In the simulator, the learner can force the device to the point of disaster to understand its limits without worrying about putting lives or investments in risk, increasing their learning curve significantly compared to what would happen if they used a real machine with all its restrictions. Likewise, the system informs the learner's performance and measures its efficiency. The economy and performance impact of this kind of creative product can represent millions of dollars and prevention of lives.

The second type regards to the use of the vast repertoire and language of digital game theory to engage and seduce
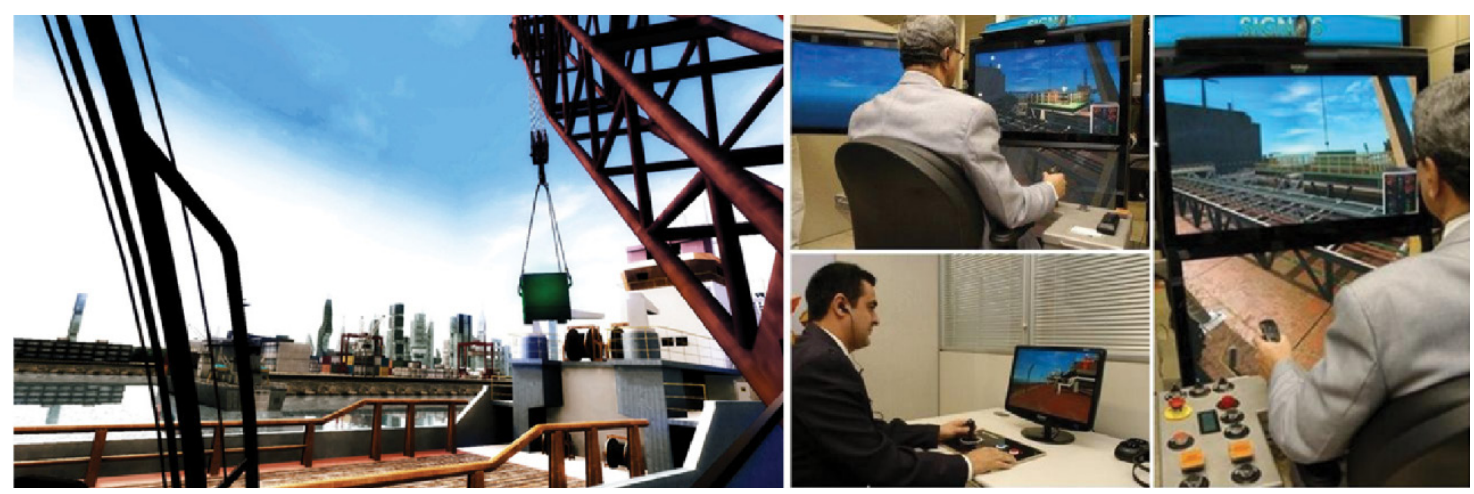

Figure 1. Onshore crane simulator. Source: Oníria (2010). 
users. In the Four Square application, for example, several game design techniques are applied to make the users not only create more content for the application (which is great for the company that owns the brand) but also for them to feel rewarded to do so. The generation of information by users - the true driver of the application - becomes a fun activity and, above all, rewarding.

The third example aims to show how the games encourage innovation when inserted in traditional contexts. The game Fold It (Figure 2), developed by a group of researchers of Science in Games at the University of Washington, is an online simulator of the physiochemical behavior of proteins related to diseases. In 10 days after the launching of the online game, among thousands of players worldwide, the crystalline structure of a protein related to the AIDS virus that was being sought for over a decade was deciphered. The structure and style of the game has managed to transform the act of playing and its network power in a creative force, solving problems from other paradigms.

Considering the above, it is not surprising that the use of games in the environmental context is not a novelty. International organizations such as Games for Change or even companies like Visa, Shell and others get important tools for discussions and engagement with their target communities regarding environmental issues from games.

Games such as Fate of the World (Red Redemption, 2011) are built based on real problems and research is carried out by environmental scientists. They allow the player to build scenarios taken from reality, increasing the complexity and interdependence of decision making by the player.

Two of the problems with environmental issues are time and geography - getting people to care about people on the other side of the planet and problems far in the future. If people can feel and see the evolution of variables in a system - such as a changing climate - it can be a better way of learning than reading lots of scientific prose. (The Guardian., 2010)

Indeed, the games gather formal characteristics that facilitate addressing issues such as those ones presented by environmental problems, which have a high degree of interdependence. When we add to that the conceptual formalization of the theories of digital games (system of rules, aesthetic dimension, technology and interface), goals (delivery experience) and production processes, we see that the mixture of easy handling and a product with high power of engagement make games a tool to be used in one of the major biases of economic and environmental issues: environmental education

\section{Material and Methods}

The project Sustainability Game, called Sustain, was developed by Digital Games Development Laboratory in a partnership with the Learning Objects Laboratory (both projects of the course Technology of Digital Games at Feevale University (Universidade Feevale)), with the Law research group at the same university and the Center for Agricultural Sciences, Biological and Environmental at Recôncavo da Bahia University (Universidade do Recôncavo da Bahia). They aim to develop a game that improves the performance and engagement of students to environmental issues.

As method, the game is thought as a Digital Learning Construct. The DLC are learning objects that work procedurally the contribution of each area being no one subordinated to another. In this logic, each area has the ability to impact the guidelines of the Construct from the tension and dialogue between the parties (Bez, et al., 2012). In the case of "Sustain", it is the result of a multidisciplinary discussion covering professors and students of Digital Games, Education, Communication, Computer Science, Biology, Environmental Studies and Law.

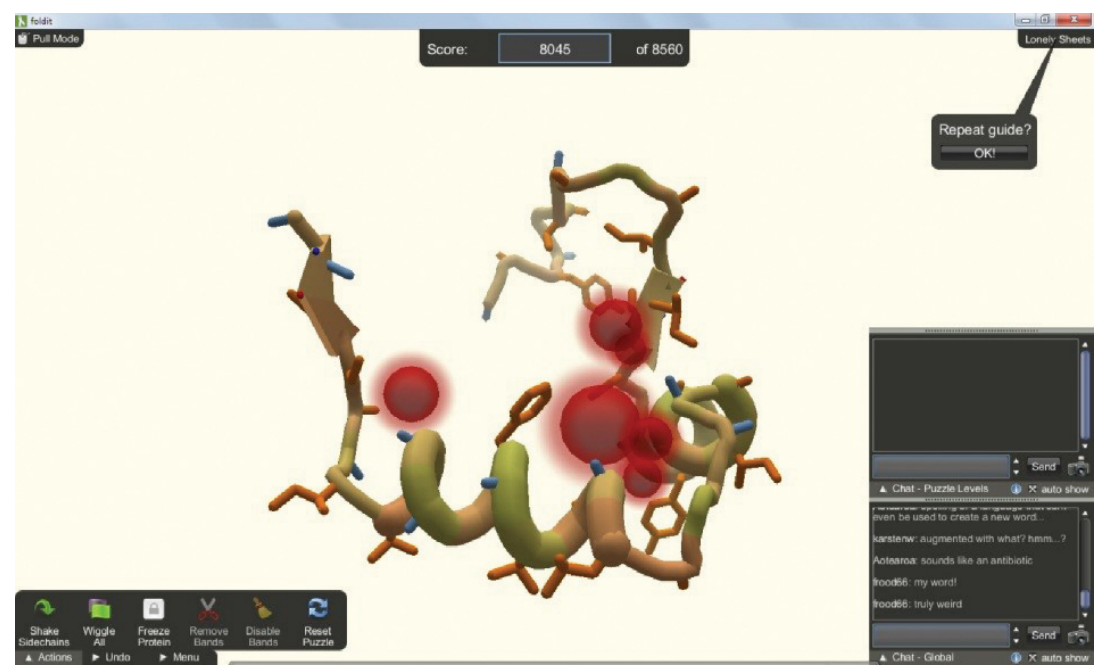

Figure 2. Screenshot of Fold It. Source: Washington University. 
The need for collaboration in such diverse areas represents one of the greatest challenges in creating this type of game. It is important to notice that, as we do not subordinate the process of building the game to one or another area (usually education), it opens up spaces where each discipline assumes responsibility, not only for the content that dominates, but for the modeling of the system and the logic governing the game.

In practice, this process requires areas to think about the final product (the game) with all its capabilities and technical limitations, forcing to stand up with positions and negotiations, based on understanding the needs and goals of each area.

In the case of Sustain, the main challenges had shown themselves since the first movements of the group: the complexity of the interactions of the natural systems and economic/social processes should be summarized in a few vectors, due to the construction needs of game design and the processes of computation. Thus, not only pedagogical needs are taken into consideration, but also the needs of game play and fun (digital games) which are expected from a game, the performance and reliability of the system (computing), the clarity of the concepts of sustainability (biology and ecology) as well as the relevance of using games in teaching environmental law (Law). The tension provided by the debate (key feature of Digital Learning Constructs) engaged areas in order to realize the role and importance of the other, opening new opportunities for discussion and new solutions to build the game.

The game covers the concepts of natural resources and environmental services from Lutzemberger (1980) and Mander (1970). Its logic is based on the affectation between these systems. A project in education area has developed for Obara et al. (2009). This project aims at the inclusion of information about the environment in the school curriculum. Callisto et al. (2011) worked to build a protocol some important tools for the training of postgraduate students to protected areas with the potential for the preservation of water supplies for urban areas. The player must manage the use of water, soil, energy, food production, reuse and reduction of waste and the degree of public awareness. In contrast, the game features vectors that are not manageable, and that put the player to face decisions that affect the life of that population: the time factor, the logic of the continuous increasing of the use of available resources, the steady growth of the population that will soon be unsustainable, and the simulation of some environmental services.

The game is designed to be used at the classroom in an integrated manner under the presence of a teacher, presenting in an expository way some basic concepts used in the game. The explanation, however, is not a condition for the game to be played and understood. For this, the game brings back from the computer sciences and technical studies of game usability and playability (tutorials, resources, sound, graphics and interface) that enable self-learning and mastery of the progressive features of the game.

This is not a contextualization of sustainability concepts, but the way you play. In fact, the game does not concerns to explain concepts, but to provide an experience of resource management, leaving the player to make connections and apprehensions of the systems that are represented there (water, soil, air, etc.) and the chains of cause and effect established between them. Likewise, the game does not bother to say what is right or what is wrong. On the contrary, lies on open interpretations of the most expensive concepts among the areas involved.

\subsection{Game description}

The game developed is a mix of two known genres: the time management, which consists in specific problem solving in a predefined time, and the real-time strategy genre, which consists in strategic management of many dimensions, predicting and solving problems between the courses of the game.

In the game called Sustain (Figure 3), the player's mission is keeping the ecosystem friendly and functional for the simulated environment inhabitants as long as possible. For this it must establish the best relations between the different game systems (population, water, energy, air, garbage and food), and those perfect individually systems as well, mastering the performance and diminishing their environmental impact.

The challenge of the game is "How long can the player keep life in this generic environment for?"

The player must change the recycling capacity of the environment by investing in new recycling construction. However, by investing in this option, the variables change

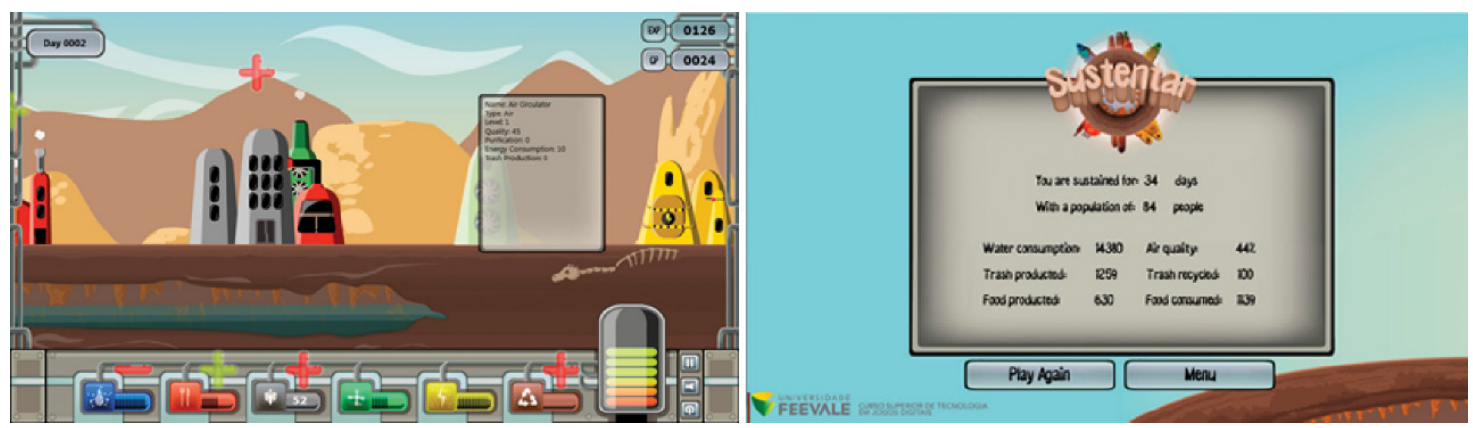

Figure 3. Screenshots of Sustentando (Sustaining). Source: the authors. 
in the game, depending on a higher power production for its operation, which could entail the necessity of building a new power station. All systems (water, food, air, population, energy and waste) have their own buildings and their features interfere with each other, the player has to find a setting that allows the ecosystem to survive longer.

At the end of the game, the player receives the quantitative data of the experience, considering the days the game spent and the consumption/accumulation/recycling systems involved. Thus, the player has the opportunity to understand the results of its actions in the game, and takes them as a starting point for a new game experience.

\section{Results}

Following the objective to evaluate the utilization of the game Sustain by a group of students of the Undergraduate Program of Law, specifically the Current Issues in Public Law class, where topics related to environmental law are studied. It was done a practice in which the students played the game in a class activity. The executed process of evaluation followed these topics.

- Quality of the practice done by the students during the evaluation class;

- Certification of the acquired knowledge during the practice.

In this process with the students, it was applied an empirical evaluation through a workshop/classroom use of the game Sustain. The workshop was held during a meeting of the classroom discipline on 11/27/2012 at Feevale University (Universidade Feevale). To make the research happens, it was necessary to split the students into two groups randomly formed as follows:

- Group A: The group of students that attended the workshop without the practical experience of the game Sustain;

- Group B: The group of students that attended the workshop with the practical experience of the game Sustain.

The activities of the workshop were divided in three parts. In the first one that lasted 15 minutes, a presentation for all the students (Group A and Group B) was held jointly addressing concepts related to sustainability. At this stage a professor gave a lecture and handed a textual material on the following topics:

- What is sustainability?

- Why is it necessary to understand our relation with the natural systems?

-What are the limitations of the sustainability?

- Human activities that require care in its immediate execution, under the penalty to lose their ability of sustainability. (These insights should be confronted with the details of the game);

- Consequences of the non-sustainability of our human systems.
Thus, in the second stage, after a 5-minute interval, it was held a distinct 30 -minute practice to each of the research groups. The practices were the following:

- Group A: held a practice conventionally used in disciplines where students must answer a fixation exercise, consisting of objective and descriptive questions, related to the topics explained in the presentation about sustainability. This practice had the answers revised with the students;

- Group B: the students in this group received as an exercise, to play the "Sustain" game for 30 minutes. During the game, students should learn to relate and manage the various environmental systems presented in the game.

At last, the third step of the evaluation was to check over the students' knowledge of the topics inserted in the practices. For 30 minutes, students from both groups answered a same survey instrument, consisting of the following sections:

- Section 1 - Identification of the participant;

- Section 2 - Assessment of theoretical explanation of the professor, about sustainability;

- Section 3 - Evaluation about the practice performed (Conventional or Game);

- Section 4 - Evaluation of knowledge.

The following are the data collected, during this third stage, regarding to sections 1 and 3 .

Group A consisted by 15 people, ages between 19 and 41 years-old, from both sexes. Of those ones, $80 \%$ do not make use of digital games. Group B also consisted by 15 students, ages between 18 and 40 years-old, from both sexes. In this group, $46 \%$ does not make use of digital games.

The first question, concerning the practice, was related to the feeling caused in the student from the initial explanations on the subject. It was observed that both groups reported feelings as interest and curiosity, these aspects represented 73\% in Group A and 75\% in Group B.

Regarding the perception that the content was reinforced by practice, in Group A, $87 \%$ stated that aspect as positive, while in Group B, 100\% of the respondents confirmed this hypothesis.

When questioned about the understanding of the concept of sustainability from the experiment, in Group A, $87 \%$ said yes, while, in Group B, the response was positive in $100 \%$.

As seen in Table 1, when asked to classify the practice held during the workshop/class, the responses of group B can be highlighted, evidencing the fact of using the game as a great or good practice to fix concepts, with $93 \%$, whereas the group A it was $60 \%$.

As to the time elapsed from the practice, group A showed, with $47 \%$, sufficient time (excellent or good), while group B, indicated $86 \%$.

In order to analyze the motivation and encouragement provided by the practice, in group A $60 \%$ of the respondents positively confirmed this hypothesis, while in group B, $87 \%$ had this perception. 
Table 1. Field research data comparison. Source: the authors.

\begin{tabular}{lrccccccccccc}
\hline & \multicolumn{2}{c}{ Great } & \multicolumn{2}{c}{ Good } & \multicolumn{2}{c}{ Regular } & \multicolumn{2}{c}{ Bad } & \multicolumn{2}{c}{ Terrible } & \multicolumn{2}{c}{$\begin{array}{c}\text { Did not } \\
\text { respond }\end{array}$} \\
\hline & A & B & A & B & A & B & A & B & A & B & A & B \\
\hline Suitable for fixing concepts & $20 \%$ & $40 \%$ & $40 \%$ & $53 \%$ & $20 \%$ & $7 \%$ & $13 \%$ & $0 \%$ & $0 \%$ & $0 \%$ & $7 \%$ & $0 \%$ \\
Sufficiency of time & $7 \%$ & $13 \%$ & $40 \%$ & $73 \%$ & $33 \%$ & $7 \%$ & $13 \%$ & $7 \%$ & $0 \%$ & $0 \%$ & $7 \%$ & $0 \%$ \\
Discussion or debate & $20 \%$ & $40 \%$ & $20 \%$ & $33 \%$ & $40 \%$ & $27 \%$ & $7 \%$ & $0 \%$ & $0 \%$ & $0 \%$ & $7 \%$ & $0 \%$ \\
Motivation and encouragement & $13 \%$ & $60 \%$ & $47 \%$ & $27 \%$ & $27 \%$ & $13 \%$ & $7 \%$ & $0 \%$ & $0 \%$ & $0 \%$ & $7 \%$ & $0 \%$ \\
$\begin{array}{l}\text { Adjusted the objective of the } \\
\text { theme }\end{array}$ & $13 \%$ & $60 \%$ & $47 \%$ & $33 \%$ & $20 \%$ & $7 \%$ & $7 \%$ & $0 \%$ & $7 \%$ & $0 \%$ & $7 \%$ & $0 \%$ \\
\hline
\end{tabular}

Regarding consistency between the contents and the practice, the group A indicated $60 \%$ consistent, whereas the group B, $93 \%$.

\section{Discussion}

One of the first things that stand out in the data analysis is that there seems to be a direct correlation between the uses of the game as good or excellent practice to fix the concepts. The difference of $33 \%$, in responses between groups $\mathrm{A}$ and $\mathrm{B}$, seems to prove the hermeneutic experience of the game advocated by Heidegger and Gadamer: the act of playing is an act of experience, in which the discovery and adaptation to the rules and logic of the game takes the player to formulate theories, plans, and act in the same act. The game, demanding the presence of the player throughout his attention, becomes a powerful tool to guide the learning process. The active participation of the student in the process of playing positively, impacts not only his perception of the activity itself, but also, in a significant way, impacts the motivation and stimulation caused by playing, as well as the perception that the proposed ludic activity game is consistent with the content being addressed.

Another important aspect that showed in the traditional activity group is the fact that the Group A demanded an extra amount of time to answer the questions properly, with only $47 \%$ of them considering the given time (30 minutes) was good/great for filling in the issues. In other hand, with the playing activity, the students of Group B considered the given amount of time good/excellent by $86 \%$ of members. While applying the traditional questionnaire, several participants of the Group A expressed concern about the time and alleged tiredness, once they left a traditional practice activity for the activity evaluation questionnaire, totaling one hour of questions and answers. On the other hand, several participants questioned whether the Group $\mathrm{B}$ could have access to the game at other times.

Finally, $100 \%$ of the participants said they understood the concept of sustainability, as opposed to $87 \%$ who underwent traditional exercise. The difference of $13 \%$ is significant if we consider the population of students in a country as the size of Brazil. Moreover, the use of this type of digital games can extend the range of the pedagogical instrument. This type of extension is viable through technologies that are also found outside the classroom, such as mobile phones and Internet Cafes.

This overview of data seems to reinforce that the use of the proposed Heidegger's hermeneutics, applied to environmental issues, offers interesting responses in Constructs of Digital Learning Production Methodology.

In the hermeneutic process, applied to environmental issues, it is important to look up the mapping rules, interpret movements and understand the varied interests and areas of complexity on the issues of environment. At the same time, there is a need for action and decision that puts the student or lawyer in a ground not fully planned.

Thinking specifically in digital games - and reinforced by Ulrich - do seem to have several similarities that bring close the act of playing with the need to understand the problems of systemic nature, which characterize the environmental issues.

Especially when it comes to the production aspects of Digital Learning Construct, Gadamer opens the way to show that the authentic hermeneutic experience is given by interpretation, understanding and application that is the backbone of his method, in which each player will conduct its operations, relying on the hermeneutic of understanding and the interdisciplinary dialogue.

The CDL requires the wrecking of hierarchies among areas - that has the same degree of autonomy and participation on the project - as well as requires them to extend the conceptual discussions of the base abstractions to the practical needs of a digital game production, compelling that even areas that do not have the communication and the computational product of their subject, to discuss and be exposed to the limitations and technological possibilities that are necessary to the reality of the educational product.

\section{Conclusion}

Regarding the game Sustain, it is important to note that, unlike the traditional exercise proposed for the Group A, this is the first experience of the game during its production process. That is, the proposed activity for the Group A (the exercise of fixing - questionnaire) is a traditional activity, whose production technique is a domain of both the researchers, being built from a strong scientific tradition, as of the experiential background by the game creators. The use of digital games for this purpose, however, does 
not have the same tradition neither a repository of scientific grounding as comprehensive as the first one.

In practice, one should take into account that there is much to build in the Constructs of Digital Learning field. Future work in this direction is the analysis of the knowledge acquired by the participants of this research, through the practice of the game Sustain (Group B) compared to the fixing exercises (Group A).

Within the mind, it can be said that associate the Game Sustain to pedagogical strategies for the teaching of environmental law is a unique way to show the difference between the thought of rationalism and what Gadamer proposes to develop. The feature of ludic experience contributes, certainly, for the student to access the existence of the classes. Object becomes the subject of learning, since it performs a hermeneutic experience. The class, while pure transmission of knowledge, is something repetitive, while the game play is something unrepeatable, there will never be a similar result, because it is a unique phenomenon in its manifestation and its appear. The game as a matter of fact in law education should be rebuilt by its players (students and teachers). Requires the observer (student), game participant, to build something, to commit, participating fully in order to talk and express themselves, externalizing their understanding.

\section{Acknowledgments}

This work was performed at the Digital Games Development Laboratory, in association with the Learning Objects Laboratory at Universidade Feevale. With support from the Undergraduate Program of Law, Graduate Program in Environmental Quality, Office of the Dean of Research and Innovation of Universidade Feevale, and, the Environmental and Biological Agricultural Sciences Center of the Universidade Federal do Recôncavo da Bahia.

\section{References}

BECK, U., 2008. La sociedad del riesgo mundial - em busca de lá seguridad perdida. Barcelona: Paidós.

BEZ, MR. and PASSERINO, LM., 2012. Dispositivo móvel Tablet na educação especial: pesquisa exploratória. In IV Congresso Internacional de Ambientes Virtuales de Aprendizaje Adaptativos y Accesibles, 2012. Cartagena das Indias. Catagena das Indias: CAVA. vol. I, p. 1-10.
CALLISTO, M., RIBEIRO, AS., SANTANA, VB., FRANÇA, JS., LIGEIRO, R., FERREIRA, WR., SILVA, D., CASTRO, D., TUPINAMBÁS, TH., SANTANA, D., SOUZA, B., GONÇALVES, F., RODRIGUES, L., ANDRADE, CB., SALES, SCM. and SOUZA, R. 2011. Rapid ecological assessment of benthic indicators of water quality: a successful capacity-building experience for Brazilian postgraduate students in ecology. Brazilian Journal of Biology $=$ Revista Brasileira de Biologia, vol. 71, no. 4, p. 937-947.

GADAMER, H-G., 1996. Estética y hermenêutica. Translation by Antônio Gómez Ramos. Madrid: Tecnos.

GADAMER, H-G., 1999. Verdade e método I. Translation by Flávio Paulo Meurer. 3th ed. Petrópolis: Vozes.

HEIDEGGER, M., 1999. Introducción a la filosofia. Translation by Manuel Jeménez Redondo. Madrid: Frónesis Cátedra Universtat de Valencia.

LUTZEMBERGER, JA., 1980. Fim do futuro? Manifesto ecológico brasileiro. Porto Alegre: Movimento.

MANDER, J., 1970. The environmental handbook. New York: Ballantine Books.

MENDES, TG., 2012. Games e educação: diretrizes de projeto para jogos voltados à educação. Porto Alegre: Programa de Pós-Graduação em Design e Tecnologia, Universidade Federal do Rio Grande do Sul. 134 p. Masters Dissertation in Design and Technology.

OBARA, AT., SUZUKI, HI., TAKEMOTO, RM., TOMANIK, A., CORREDATO-PERIOTTO, TR. and SILVA-DIAS, MA., 2009. Environmental education in the Upper Paraná River floodplain, municipality of Porto Rico (Paraná State), Brazil. Brazilian Journal of Biology $=$ Revista Brasileira de Biologia, vol. 69, no. 2, supplement 2, p. 627-635. PMid:19738969.

ONÍRIA. 2010. Onshore Crane Simulator.

PRENSKY, M., 2001. Digital Game-Based Learning. St. Paul: Paragon House.

\section{RED REDEMPTION, 2011. Fate of the World.}

ROHDEN, L., 2002. Hermenêutica filosófica: entre a linguagem da experiência e a experiência da linguagem. São Leopoldo: Unisinos.

The Guardian, 2010. Climate Change for Computer Games. The Guardian. Available from: <http://www.guardian.co.uk/ environment/2010/oct/31/climate-change-computer-game $>$. Access in: 31 Oct. 2010.

ULRICH, M., 1997. Games / Simulations about environmental issues existing tools and underlying concepts. In Proceedings of the 28th Annual International Conference of the International Simulation and Gaming Association, 1997. Tilburg. Tilburg: The Netherlands. p. 301-311. 